\title{
CHANGE OF LECTURERS' ROLE IN APPLYING PROBLEM-BASED LEARNING IN UNIVERSITY STUDIES
}

\author{
Jurgita Lenkauskaitè \\ University Šiauliai, Lithuania
}

\begin{abstract}
The article deals with the change in lecturers' role that takes place when traditional study process is being replaced by problem-based learning. In problem-based learning a lecturer becomes a facilitator not authoritatively transferring knowledge to students but contributing to the construction of social knowledge, in which an important role is given to students' knowledge conditioned by their unique experience, learners' interaction, their relations with various subjects of social environment. Together with lecturer's changing role problem-based learning also provokes the transformation of power relations in university studies. Facilitation that makes up the basis of a lecturer's role in problem-based learning causes quite many challenges because it is an unstructured process requiring lecturer's ability to flexibly respond to students' learning needs, provide them adequate support in a right way and time, etc.
\end{abstract}

Keywords: lecturers' role, problem-based learning, university studies.

\section{Introduction}

Problem-based learning (PBL) strategy implies specific transformation of the conventional lecture-based learning process. Transformation involves the shift from teacher-centred to learner-centred study process (Dole et al., 2016). Roles performed by lecturers shift accordingly. In a conventional learning process, a lecturer is the person who manages and conveys knowledge, while students form a large passive audience. The lecturer provides references to learning sources, acts as a curriculum expert and assesses the learning outcomes. In PBL, a lecturer is assigned with the role of a facilitator, consultant. The lecturer's function of control over the study process is replaced by the main function of providing favourable conditions enabling students to demonstrate critical thinking, find appropriate sources for problem analysis and solving, create knowledge rather than consume the knowledge discovered by another person and furnished to them. PBL involves student learning in groups that often gather without the lecturer's knowledge or intervention. As a result, the lecturer 
is no longer responsible for the entire learning process and is not capable of assessing students' achievements on his/her own.

Problem-based learning features change in lecturer-student relations. The two parties become able to learn from each other, cooperate in problem analysis and solving. The former power relationship is deformed and new trends of the relationship emerge. Under the experience-based learning approach (see Andresen et al., 1999), students' social experience becomes empowered, and students' accounts of their living world, relations with their surrounding social environment become important for the learning process, which is not given credit in the conventional lecture-based study process.

Nonetheless, lecturers are often reluctant to let go of their traditional roles and, as soon as faced with certain difficulties in the PBL process, are inclined to return to conventional teaching and learning methods (Dolmans et al., 2001). Challenges emerging in the PBL process often prompt lecturers to apply it in a fragmented way, often returning to conventional roles and not covering the entire rationale behind PBL that demonstrates its true potential only if applied consistently throughout the study process. Lecturers have been noted to apply mixed-type problem-based learning (Lenkauskaitė \& Mažeikienè, 2012), where the role of a facilitator is combined with the conventional role of lecture delivery and curriculum conveyance.

Relevance of the topic is implied by the demand for student-centred learning, which could be met by application of PBL. Lecturer's roles that largely determine the process and outcomes of PBL should also be considered in a more comprehensive manner as part of the attempt to validate the PBL effectiveness. Emphasis on the importance of students' active involvement, their team work, weakening of the lecturer's role of the epistemic authority that conveys knowledge does not mean that the lecturer "does not do anything" or becomes less important. Research shows that curriculum change is closely related to lecturers' belief (Wilkie, 2004). Roles performed by the lecturer in the PBL process are fairly unconventional if viewed from the conventional standpoint on the university studies. The emerging challenges, fragmented application of the role of a facilitator signal the need for more comprehensive analysis of the lecturer's roles that are subject to transformation in the PBL process.

The research aim is to analyse the transformation of lecturer's roles and the associated challenges in application of problem-based learning in university studies.

The paper follows the method of scientific literature analysis. 


\section{The Role of a Facilitator in Problem-Based Learning}

Analysis of student-lecturer interaction on the curriculum level implies that a lecturer traditionally is the authority figure and source of information, while in PBL, as students take over the learning initiative, the lecturer becomes a facilitator who provides feedback (Azer, 2008). Control-associated lecturer's role in the PBL process could be noticed to diminish, while the importance of the role related to self-directed learning empowerment of students increases.

Transformation of the lecturer's role could be identified throughout the study process. His/her role primarily manifests itself in adoption of the appropriate ill-structured problem, which would encourage discussions among students, raise a cognitive conflict (see Piaget, 1972) and provoke their learning process. During PBL, a lecturer performs the role of a facilitator (Savin-Baden, 2007) who provides assistance to the PBL student team to ensure collective work and progress in problem analysis and solving.

A lecturer who strives to perform the facilitator's role properly needs to let go of the conventional roles of being an expert, delivering a lecture, presenting the entire curriculum, information and sources available to him/her. In PBL, other actors may emerge next to the lecturer and become new learning sources. Besides the students who act as teachers to themselves and to each other, other lecturers, visiting practitioners, other staff members of the school of higher education, e.g., librarians, may as well join the learning process (see Eldredge, 2004).

PBL is associated with real-life problem solving, and participants of the social world related to the problems analysed and solved by the students, in one way or another, often become involved in the process of university studies. For this reason, the lecturer is no longer capable of controlling the entire knowledge flow, but may support students in understanding the importance of certain information, make valuable input into development of the discussions. Participants of the PBL process face the postdisciplinarity phenomenon (SavinBaden \& Wilkie, 2004), where real-life problem analysis requires multidisciplinary knowledge, and problem solving no longer resorts to an academic setting only, but may also take place in schools, communities, business companies, etc.

The PBL process involves considerable share of time spend by students in their heterogeneous teams formed of students with diverse experiences and accumulating diverse information from various learning sources. It is important that the lecturer listens attentively to the team discussions, asks appropriate questions that activate the available knowledge and provoke new knowledge in order to facilitate students' learning and problem analysis. Lecturer's assistance should be consistent with the issues faced by the team. Different situation 
require different assistance in PBL (Savin-Baden \& Major, 2004). A. J. Neville (1999), who has analysed lecturer's role in PBL processes, has arrived at the conclusion that lecturer's role cannot be the same for all PBL situations. The role varies depending on the students' level, study programme.

Facilitation may cross different levels until students are able to demonstrate self-directed learning. Certain authors refer to this process as scaffolding (e.g., Salonen \& Vauras, 2006), which literally means temporary support in the process of building a structure. In educational context, this metaphor for support also means temporary structure employed by educators to assist learners in problem analysis and solving. This assistance may, however, diminish gradually. It is important to employ an appropriate method of assistance to students and use it not because it is conventional and more simple, but because it is timely and may provide the best support to students in learning, analysing and solving the existing and future problems that may arise not only during the studies, but in their professional activity as well. It is therefore important that lecturers are positive towards students' self-guided learning and put effort in approaching this process. Proper facilitation manifests itself on the level of knowledge, abilities and attitudes (Pourshafie \& Murray-Harvey, 2013).

It is important that the facilitator in the PBL process asks appropriate questions, is open to various questions from students and ready to participate in the discussions (Chan, 2016). Authors analysing PBL have noted that the success of facilitation is related to proper communication that implies minimum intervention, maintenance of mutual relations, recognition of differences between individual students, assistance in achieving the expected learning outcomes, etc. (Chan, 2016). It is important to pay attention not only to verbal, but also nonverbal communication (Savin-Baden \& Major, 2004), which may contribute to successful development of discussions, create an inviting learning environment. Lecturers' role has been noted to change in terms of understanding the importance of dialogue in the learning process, not only between the facilitator and an individual student, but between the students as well (Wilkie, 2004). All the efforts for the purpose of promoting successful interaction and communication between lecturers and students as recommended by the authors analysing PBL suggest that their roles in the study process are subject to transformation, with the lecturer becoming a fully-fledged participant in problem analysis and decision making.

Assessment of students' achievements in PBL is no longer the prerogative of a lecturer only. The function of a facilitator is, however, important in terms of feedback provision. PBL puts emphasis on formative assessment throughout the study process that may make significant contribution to successful outcomes of the PBL. Feedback provided by the facilitator to students should be informal and not abstract (Savin-Baden \& Major, 2004). It has been emphasized that the 
lecturer should provide feedback through his/her own prism, specifying his/her opinion and reasoning, rather than referring to some aspects to be corrected in PBL. Hence, it is also the lecturer's rhetoric in PBL that should be oriented towards discussions and search for a consensus rather than simply verbalising declarative statements and demonstrating positions of the epistemic authority.

\section{Transformation of Power Relations along with Change of Lecturer's Role in PBL}

Lecturers' role in the conventional study process as of the epistemic authorities who passively convey the curriculum to student audience emphasizes unequal relations of the study process participants. Pursuant to the theory behind power relations by M. Foucault (see Volkers, 2008), traditional education receives criticism for instrumentalizing lecturer-student relations and putting all efforts into creating conditions for knowledge conveyance.

PBL is based on transition to creation of the knowledge that empowers students' active involvement. Supporting student-centred learning process is an integral part of lecturer's role in creation of positive, friendly, open mutual relations with students in view of their diversity and need to develop the applicable knowledge (Ching et al., 2002). The altered relations between lecturers and students have positive effect on micro-climate inside the classroom (Dole et al., 2016), which leads to better quality of studies, encourages students to ask questions of interest and engage in discussions.

Researchers have been noting more democratic social relations in a successful PBL process compared to conventional classes (Barrett, 2004). Democratic relations in PBL imply diversity of opinions, opportunity to express own position, hear different stakeholders related to the problem analysed. Hence, the "truth" in the study process does not belong to an epistemic authority, but is rather the most promising interpretation discovered by consensus (Gordon, 2009).

Nonetheless, researchers analysing PBL (e.g., Wilkie, 2004) have noted that the shift from lecturer-centred to student-centred learning is not immediate, as both the emotional and cognitive domains of participants in the study process should change gradually. It has been noted that PBL discussions are sometimes focused on facilitators rather than empower the students. This means that the teaching and learning methods applied are not a guarantee of equal relations or expected students' active involvement.

One of the most apparent methods of establishing long-standing power relations in education is assurance of control. The term panopticon employed by M. Foucault (1975) could be used in analysing the control important to university studies. Panopticon is an architectural form featuring a central tower 
occupied by a watchman (in this case - a lecturer) and cells, where individuals (who may be the students) may be placed, one in each cell. A person is perfectly individualized and always visible, but the side walls prevent him from establishing any contact with the occupants of neighbouring cells. He/she becomes an object of information, but never a subject of communication. The system of panopticon secures order, the power of an external authority, separation of learners from each other. This prevents them from cooperating and denies any possibility for manifestation of epistemic diversity.

Examination is another tool clearly reflecting power relations in university studies. Conventional examination involves a student reproducing, repeating what has been presented to him/her by the lecturer. The student is required to prove that he/she has successfully mastered the information. The lecturer demonstrates his/her power at the examination by combining the technique of hierarchical observation and normalizing sanction (Foucault, 1975). In conventional studies, examination serves largely to separate students from each other and apply a sanction according to the level of detail that the students have succeeded in demonstrating while reproducing the curriculum. Hardly would the role of a lecturer who applies sanctions, oversees order be consistent with the student-centred PBL and his/her empowerment in the study process.

In the process of change of university studies, and with more emphasis being put on the importance of identification and solution of real-life problems during the studies, the role of a lecturer is also subject to considerable transformation. In the PBL process, the system of panopticon is replaced by open and active cooperation between all participants of the study process, discussions that destroy hierarchical relations and establish equal, democratic relations. In PBL, examination is also subject to essential transformation. It no longer performs the function of sanctioning, a lecturer is no longer an allknowing expert or a supervisor who controls the entire study process. In this case, students' achievements are assessed not only by the lecturer, but also by the students, other participants of the PBL process.

While performing the function of an assistant, the lecturer needs to trust students more and delegate a great share of responsibility to them, thus considerably restricting own power. This becomes particularly evident in larger groups of students, where lecturers find it difficult to assist, control all students, observe their team dynamics, etc. In this case, the lecturer may assign students to be his/her assistants in handling PBL functions in teams and inform the lecturer on important aspects of problem analysis. B. J. Duch (2001) has referred to this principle as the peer tutor model and, in its description, has noted that a student who has already completed the course could become such a mediator who assists the participants of university studies. 
Analysis of lecturer's role often shows that mechanisms of power are rather subtle in the practice of education and difficult to recognize. As a result, such mechanisms often succeed in avoiding critical transformation. Having analysed the links between the theory of power relations and issues in education, A. Volkers (2008) asserts that more reflexive thinking would be desirable in attempts to identify power relation in the process of (self-)education. He believes that practicing educators rarely view their activity as implementation of power. In shifting their focus on equal, democratic relations in university studies, lecturers should make critical assessment of own role an integral part of their activity.

\section{Challenges of the Lecturer's Changing Role}

With the conventional study process transforming into PBL, lecturers face various challenges that may provoke concern or even hostility towards PBL. Participants of the study process often have concerns that their regular work model might be ruined, find it difficult to understand and accept new roles, duties, worry whether the learning outcomes will be measured clearly and assessed properly or not (Margetson, 1997; Hung et al., 2008).

For PBL to encompass the entire study process rather than remain a fragmented technique, the essential transformation in understanding of what teaching and learning are must take place. This is particularly challenging for lecturers whose previous activity has involved lecture delivery and instruction (Hmelo-Silver, 2004). Hence, a lecturer must prepare himself/herself for PBL application by both upgrading own abilities in empowerment of students in the study process and changing own attitudes towards the lecturer's role.

Initially, lecturers who start applying PBL often find it difficult to let go of the control they used to enjoy and learn to share the responsibility. They habitually make attempt to ask PBL teams specific questions that may show a very clear path towards solution of a problem rather than encourage students to find this path themselves (Savin-Baden \& Wilkie, 2004). In provision of information to the maximum extent possible, lecturers try to keep the control, as they are convinced that students will not gain the necessary knowledge in any other way. Understanding facilitation theoretically often turns into giving instructions to students in practice. Lecturer's attempts to become an equal member of a PBL team may also be challenging. In this case, it is important to be aware of the possibility for the lecturer's word to become decisive in analysing and solving problems.

Concern about the loss of control in the PBL process is quite often replaced by educators' astonishment that the learners are capable of controlling their learning (Dole et al., 2016). Hence, the first step in the transformation of 
educators' role - letting go of the control functions - may become the prerequisite for students' self-guided learning.

It should be noted that a considerable share of challenges is faced by lectures not only at the stage of preparation for PBL or its beginning, but also in the course of PBL, during students' team work. A PBL facilitator must be prepared for the possibility of disputes and conflicts, negative group dynamics in student teams (Hmelo-Silver, 2004). Students often become disappointed in team work, if not all group members contribute equally to problem analysis and solving, some of the students are even inclined to not attend the PBL sessions or do not study individually at the designated time and are incapable of demonstrating effective support to discussion (Dolmans et al., 2001).

Preventing students from feeling disappointment in PBL team work or helping them improve their team work is not always an easy task for lecturers. One of the reasons is that lecturers tend to address difficulties emerging in PBL from the lecturer-centred perspective. Authors analysing PBL (Dolmans et al., 2001) have noted that, having faced inadequate preparation for team work, lecturer sometimes decides to deliver lecture on the topic that the students have been expected to study individually and discuss in the team.

Lecturers, however, should change their role and empower students more, even in more complicated situations. For example, lecturers are recommended to encourage students to explain information using own words, convey it to each other, apply the information received to various situations, etc. This stimulates students' sense of responsibility for own learning and is in line with the principles of PBL - the student-centred learning approach. The issue of nonattendance of a PBL session could be solved by application of formative assessment throughout the study process, empowerment of students to assess other student's and own contribution into problem analysis.

Uncertainty in the notion of facilitation, necessity to align own actions with the unique learning context present considerable challenge to lecturers who apply PBL: "good facilitation is not about methods, but about possessing an astute awareness of the unique learning situations in the classroom, and being able to respond appropriately to each situation such that possibilities for learning are created" (Goh, 2014, p. 160). Avoidance of uncertainty, fear of losing control, concern about insufficiently conveyed curriculum are the signs of the period of transition from conventional study process to PBL that reflect the necessity for change of the lecturer's role.

A lecturer has to be fully aware that students' learning depends on a number of components, such as motivation, aptitude, self-perception, socialisation, gender, cultural, social background, etc. (Weber, 2007). More complex situation emerges where non-conventional social actors become involved in the study process. The lecturer is therefore required to be able to 
control this diversity and motivate the students to recognize the attributes of this diversity and make use of it as of the potential in the studies rather than view it as an obstacle towards PBL goals.

\section{Conclusions}

Problem-based learning as a student-centred educational strategy implies transformation of conventional studies, including the lecturer's role. Lecturer's role in PBL is best defined by the concept "facilitator", meaning that a lecturer becomes a person who facilitates students' activity in problem analysis and solving, creates favourable conditions for students to engage in self-guided learning.

Lecturer's changing role implies new student-lecturer power relations. The control mechanisms, expression of the epistemic authority, sanctioning examination techniques prevailing in conventional studies are replaced by discussions between students and lecturers on equal terms, empowerment of new study actors in PBL. The change of power relations is only possible if the hegemonic power is recognized and acknowledged as unacceptable. Lecturer's reflexive self-assessment of his/her role and positive attitude towards the change may help identify and eliminate the power mechanisms manifesting themselves in a subtle way in the educational discourse.

Ill-structured problem, new actors in the study process, various sources, learners' varying experiences make the PBL process quite complex. Lecturers' roles determined by the PBL specifics, unstructured facilitator's activity, requirement to adapt to various situations in a flexible manner present plenty of challenges, in particular, where lecturer's previous experience has been related predominately to delivery of conventional lectures, summative assessment, and student instruction. Nonetheless, lecturers' desire to master the new roles, overcome the emerging challenges may stimulate rich discussions, expression of diverse attitudes, students' self-guided learning, discovery of innovative, creative problem analysis paths and solutions, which corresponds to the essence behind PBL.

\section{References}

Andresen, L., Boud, D., \& Cohen, R. (1999). Experience-Based Learning. In: Foley, G. (Ed.) Understanding Adult Education and Training (pp. 225-239). Sydney: Allen \& Unwin.

Azer, S. (2008). Navigating Problem-based learning. Sydney: Elsevier Press.

Barrett, T. (2004). Researching the Dialogue of PBL Tutorials: a Critical Discourse Analysis Approach. In: Savin-Baden, M., Wilkie, K. (Eds.) Challenging Research into Problembased Learning (pp. 93-102). Buckingham: Open University Press. 
Chan, C. K. Y. (2016) Facilitators' perspectives of the factors that affect the effectiveness of problem-based learning process. Innovations in Education and Teaching International, 53(1), 25-34.

Ching, K., Murphy, D., \& Jenkins, W. (2002). The teacher's role in supporting a learnercentered learning environment: voices from a group of part-time postgraduate students in Hong Kong. International Journal of Lifelong Education, 21(5), 462-473.

Dole, S., Bloom, L., \& Kowalske, K. (2016). Transforming Pedagogy: Changing Perspectives from Teacher-Centered to Learner-Centered. Interdisciplinary Journal of ProblemBased Learning, 10 (1). Retrieved January 11, 2017, from http://dx.doi.org/ 10.7771/1541-5015.1538

Dolmans, D., Wolfhagen, I., Vleuten, C., \& Wijnen, W. (2001). Solving problems with group work in problem-based learning: hold on to the philosophy. Medical Education, 35, $884-889$.

Duch, B. J. (2001). Writing Problems for Deeper Understanding. In: Duch, B. J., Groh, S. E., Allen, D. E. (Eds.) The Power of Problem-Based Learning (pp. 47-59). Sterling, VA: Stylus.

Eldredge, J. D. (2004). The librarian as tutor/facilitator in a problem-based learning (PBL) curriculum. Reference Services Review, 32 (1), 54-59.

Foucault, M. (1975). Discipline and Punish: the Birth of the Prison. New York: Random House.

Goh, K. (2014). What Good Teachers Do to Promote Effective Student Learning in a Problem-Based Learning Environment. Australian Journal of Educational \& Developmental Psychology, 14, 159-166.

Gordon, M. (2009). Toward A Pragmatic Discourse of Constructivism: Reflections on Lessons from Practice. Educational Studies, 45, 39-58.

Hmelo-Silver, C. E. (2004). Problem-based learning: What and how do students learn? Educational Psychology Review, 16 (3), 235-266.

Hung, W., Jonassen, D. H., \& Liu, R. (2008). Problem-based learning. In: Spector, J. M., van Merriènboer, J. G., Merrill, M. D., \& Driscoll, M. (Eds.) Handbook of research on educational communications and technology (pp. 485-506). Mahwah, NJ: Erlbaum.

Lenkauskaitè, J., \& Mažeikienè, N. (2012). Challenges of Introducing Problem-Based Learning (PBL) in Higher Education Institutions: Selecting and Using Problems. Social Research, 2 (27), 78-88.

Margetson, D. (1997). Why is Problem-based learning a Challenge? In: Boud, D., Feletti, G. E. (Eds.). The challenge of problem-based learning. (pp. 36-44). London: Kogan Page.

Neville, A. J. (1999). The problem-based learning tutor: Teacher? Facilitator? Evaluator? Medical Teacher, 21 (4), 393-401.

Piaget, J. (1972). Intellectual evolution from adolescence to adulthood. Human Development, $15,1-12$.

Pourshafie, T., \& Murray-Harvey, R. (2013) Facilitating problem-based learning in teacher education: getting the challenge right. Journal of Education for Teaching, 39 (2), 169180.

Salonen, P., \& Vauras, M. (2006). Von der Fremdregulation zur Selbstregulation: die Rolle von sozialen Makrostrukturen in der Interaktion zwischen Lehrenden und Lernenden [From other-regulation to self-regulation: the rolle of social macro-patterns in teacherlearner interaction]. In: Baer, M., Fuchs, M., Füglister, P., Reusser, K., \& Wyss, H. (Eds.) Didaktik auf psychologischer Grundlage. Von Hans Aeblis kognitionspsy- 
Proceedings of the International Scientific Conference. Volume I, May 26 $6^{\text {th }}-27^{\text {th }}$, 2017. 260-270

chologischer Didaktik zur modernen Lehr- und Lernforschung (pp. 207-217). Bern: h.e.p. Verlag.

Savin-Baden, M., \& Major, C. H. (2004). Foundations of problem-based learning. Maidenhead: Open University Press.

Savin-Baden, M., \& Wilkie, K. (2004). Exploring the Impact of Discipline-based Pedagogy on Problem-based Learning through Interpretive Meta Ethnography. In: Savin-Baden, M, Wilkie, K. (Eds.) Challenging Research into Problem-based Learning (pp. 190205). Buckingham: Open University Press.

Savin-Baden, M. (2007). Facilitating Problem-Based Learning. Buckingham: Open University Press.

Volkers, A. (2008). Wissen und Bildung bei Foucault: Aufklärung zwischen Wissenschaft und ethisch-ästhetischen Bildungsprozessen [Knowledge and Education according to Foucault: the Essence behind Science and Ethnic-Aesthetic Process of Education]. Wiesbaden: VS Verlag für Sozialwissenschaften.

Weber A. (2007). Problem-Based Learning. Bern: h.e.p. Verlag.

Wilkie, K. (2004). Becoming Facilitative: Shifts in Lecturers' Approaches to Facilitating Problem-based Learning. In: Savin-Baden, M., Wilkie, K. (Eds.) Challenging Research into Problem-based Learning (pp. 93-102). Buckingham: Open University Press. 